\title{
Bovicin HC5, a bacteriocin from Streptococcus bovis HC5
}

\author{
Hilário C. Mantovani, ${ }^{1}$ Haijing $\mathrm{Hu}^{2}{ }^{2}$ Randy W. Worobo ${ }^{2}$ \\ and James B. Russell ${ }^{1,3}$
}

Author for correspondence: James B. Russell. Tel: +1 607255 4508. Fax: +1 6072553904. e-mail: jbr8@cornell.edu

\footnotetext{
1,2 Section of Microbiology ${ }^{1}$ and Department of Food Science and Technology (NYSAES) ${ }^{2}$

Cornell University, Ithaca, NY 14853, USA

3 Agricultural Research Service, USDA, Ithaca, NY 14853, USA
}

\begin{abstract}
Previous work indicated that Streptococcus bovis HC5 had significant antibacterial activity, and even nisin-resistant $S$. bovis JB1 cells could be strongly inhibited. S. bovis HC5 inhibited a variety of Gram-positive bacteria and the spectrum of activity was similar to monensin, a commonly used feed additive. The crude extracts (ammonium sulfate precipitation) were inactivated by Pronase $E$ and trypsin, but the activity was resistant to heat, proteinase $K$ and $\alpha$-chymotrypsin. Most of the antibacterial activity was cell associated, but it could be liberated by acidic $\mathrm{NaCl}(100 \mathrm{mM}, \mathrm{pH} 2 \cdot 0)$ without significant cell lysis. When glycolysing $S$. bovis JB1 cells were treated with either crude or acidic $\mathrm{NaCl}$ extracts, intracellular potassium declined and this result indicated the antibacterial activity was mediated by a pore-forming peptide. The peptide could be purified by HPLC and matrix-assisted laser desorption ionization time-of-flight analysis indicated that it had a molecular mass of approximately $2440 \mathrm{Da}$. The terminal amino acid sequence was VGXRYASXPGXSWKYVXF. The unnamed amino acid residues (designated by $X$ ) had approximately the same position as dehydroalanines found in some lantibiotics, but samples that were reduced and alkylated prior to Edman degradation did not have cysteine residues. The only other bacteriocin that had significant similarity was the lantibiotic precursor of Streptococcus pyogenes SF370, but the identity was only $55 \%$. Based on these results, the bacteriocin of $S$. bovis HC5 appears to be novel and the authors now designate it as bovicin HC5.
\end{abstract}

Keywords: rumen, lactic acid bacteria, purification, N-terminal amino acids

\section{INTRODUCTION}

Beef cattle in the United States are routinely fed antibiotics to alter ruminal fermentation, and this alteration is mediated by a decrease in Gram-positive species that produce large amounts of hydrogen, a precursor of methane, and ammonia, a wasteful end product of protein degradation (Russell \& Strobel, 1989). Monensin, the most common feed additive, is not used by physicians and does not seem to increase antibiotic resistance, but the widespread use of antibiotics in animal feed has been criticized (Russell \& Rychlik, 2001). Some Gram-positive ruminal bacteria produce bacteriocins that inhibit other related species

Abbreviations: MALDI-TOF, matrix-assisted laser desorption ionization time-of-flight; TFA, trifluoroacetic acid.
(Kalmokoff et al., 1996) and in vitro experiments indicated that the bacteriocins nisin and monensin had similar effects on ruminal fermentation (Callaway et al., 1997).

Nisin is too expensive to be used as a feed additive and experiments with the ruminal bacterium Streptococcus bovis indicated that resistance developed quickly (Mantovani \& Russell, 2001). Whitford et al. (2001) screened several ruminal streptococci for their ability to produce bacteriocins, and they purified and sequenced a peptide from Streptococcus gallolyticus LRC0255 (bovicin 255). Bovicin 255 inhibited some freshly isolated strains of $S$. bovis, but many isolates were not inhibited and adaptation greatly decreased its potential activity (Mantovani et al., 2001). Because nisin-resistant $S$. bovis JB1 could not be inhibited by bovicin 255, it appeared that there was a common mechanism of resistance. 
Ruminal isolations yielded a lactic-acid-producing bacterium (HC5) that was identified by $16 \mathrm{~S}$ rDNA to be $S$. bovis (Mantovani et al., 2001). S. bovis HC5 had a broader antibacterial spectrum than $S$. gallolyticus LRC0255 and freshly isolated strains of S. bovis did not adapt to S. bovis HC5 (Mantovani et al., 2001). The antibacterial activity of $S$. bovis HC5 appeared to be a bacteriocin, but further work was needed to demonstrate that it was indeed a pore-forming peptide. The following experiments describe the purification and characterization of the $S$. bovis HC5 bacteriocin.

\section{METHODS}

Cells and growth. Nisin-sensitive and -resistant S. bovis JB1 (Mantovani \& Russell, 2001) and S. bovis HC5 were previously described (Mantovani et al., 2001). The bacteria were grown anaerobically in a basal medium $\left(39^{\circ} \mathrm{C}\right)$ that contained (per litre): $22 \mathrm{mmol}$ glucose, $1.7 \mathrm{mmol} \mathrm{K}{ }_{2} \mathrm{HPO}_{4}$, $2.1 \mathrm{mmol} \mathrm{KH}_{2} \mathrm{PO}_{4}, 3.6 \mathrm{mmol}\left(\mathrm{NH}_{4}\right)_{2} \mathrm{SO}_{4}, 8.3 \mathrm{mmol} \mathrm{NaCl}$, $0.75 \mathrm{mmol} \mathrm{MgSO}_{4} .7 \mathrm{H}_{2} \mathrm{O}, 0.43 \mathrm{mmol} \mathrm{CaCl} .2 \mathrm{H}_{2} \mathrm{O}, 2.8 \mathrm{mmol}$ cysteine hydrochloride, $38 \mathrm{mmol} \mathrm{Na}_{2} \mathrm{CO}_{3}$, Casamino acids $\left(5 \mathrm{mg} \mathrm{ml}^{-1}\right.$; Difco), Trypticase (a pancreatic digest of casein, $10 \mathrm{mg} \mathrm{ml}^{-1}$; BBL Microbiology Systems), $5 \mathrm{~g}$ yeast extract, vitamins and minerals (Cotta \& Russell, 1982). The basal medium was prepared under $\mathrm{O}_{2}$-free $\mathrm{CO}_{2}$ and was dispensed into tubes $(18 \times 150 \mathrm{~mm})$ that were sealed with butyl rubber stoppers. To release the bacteriocin from the cells, Tween 80 $\left(1 \mu \mathrm{l} \mathrm{ml} l^{-1}\right)$ was sometimes added to the basal medium. Basal medium was adjusted to $\mathrm{pH} 6.7$ with $\mathrm{NaOH}$ and glucose fermentation never caused $>0 \cdot 2$ unit decrease in $\mathrm{pH}$. Growth was monitored via changes in optical density $(1 \mathrm{~cm}$ cuvette, $600 \mathrm{~nm}$, Gilford 260 spectrophotometer) and the ratio of cell protein to optical density was $160 \mu \mathrm{g}$ protein $\mathrm{ml}^{-1}$ per optical density unit.

Spectrum of activity. S. bovis HC5 was spotted onto basal medium plates and these plates were incubated anaerobically for $24 \mathrm{~h}$ at $39^{\circ} \mathrm{C}$. Molten agar (basal medium, $4 \mathrm{mg}$ glucose $\mathrm{ml}^{-1}$ ) inoculated with target bacteria (approx. $10^{6}$ viable cells $\mathrm{ml}^{-1}$ ) was poured over agar plates that already had a $S$. bovis HC5 colony (deferred antagonism assay). The agar overlays were incubated anaerobically for $4 \mathrm{~h}$ at $25^{\circ} \mathrm{C}$ (a temperature that does not allow growth of most ruminal bacteria). The agar overlays were then incubated anaerobically at $39^{\circ} \mathrm{C}$ for $48 \mathrm{~h}$ and zones of clearing were measured.

Crude extracts of the S. bovis HC5 bacteriocin. Stationaryphase $S$. bovis HC5 cells were harvested by centrifugation $\left(20 \mathrm{~min}, 8200 \mathrm{~g}, 4^{\circ} \mathrm{C}\right)$. The cell-free supernatant was treated $\left(4^{\circ} \mathrm{C}, 1 \mathrm{~h}\right)$ in stepwise fashion with increasing amounts of $\left(\mathrm{NH}_{4}\right)_{2} \mathrm{SO}_{4}$, and precipitated materials were harvested by centrifugation $\left(30 \mathrm{~min}, 8200 \mathrm{~g}, 4^{\circ} \mathrm{C}\right)$. The $40-60 \%\left(\mathrm{NH}_{4}\right)_{2} \mathrm{SO}_{4}$ fraction was resuspended in $\mathrm{K}_{2} \mathrm{HPO}_{4}$ buffer $(6.6 \mathrm{ml}, 100 \mathrm{mM}$, $\mathrm{pH} 6.0)$ and dialysed (3500 $M_{\mathrm{r}}$ cut-off; Pierce Chemicals) against potassium phosphate buffer. Crude extracts were in some cases treated with peptidases and proteinases $(4 \mathrm{U}$ Pronase E, $11.3 \mathrm{U}$ trypsin, $12 \mathrm{U}$ proteinase $\mathrm{K}, 41 \mathrm{U} \alpha$ chymotrypsin $\mathrm{ml}^{-1}$ ) and activity was assessed by adding these extracts to agar wells that had been cut into agar plates inoculated with $S$. bovis JB1 $\left(10^{5}\right.$ cells $\left.\mathrm{ml}^{-1}\right)$. The agar plates were incubated anaerobically at $39^{\circ} \mathrm{C}$ and bacteriocin activity was assessed from the size of the zone of clearing.

Intracellular potassium. Stationary phase S. bovis JB1 cells $\left(10 \mathrm{ml}\right.$, approximately $160 \mu \mathrm{g}$ protein $\mathrm{ml}^{-1}$ ) were harvested by centrifugation $\left(4000 \mathrm{~g}, 15 \mathrm{~min}, 22^{\circ} \mathrm{C}\right)$, washed anaerobically in basal medium lacking ammonia, and resuspended in $10 \mathrm{ml}$ of the same medium. The washed cell suspensions were energized with glucose $\left(22 \mathrm{mmol} \mathrm{ml} \mathrm{m}^{-1}\right)$ and some suspensions were treated with either nisin $(1 \mu \mathrm{M})$ or partially purified $S$. bovis HC5 bacteriocin (amount equivalent to a culture density of $160 \mu \mathrm{g}$ protein $\left.\mathrm{ml}^{-1}\right)$. Samples $(1 \mathrm{ml})$ were centrifuged $\left(13000 \mathrm{~g}, 5 \mathrm{~min}, 22^{\circ} \mathrm{C}\right)$ through $0.3 \mathrm{ml}$ silicon oil $(1: 1$ ratio, Dow-Corning 550 and 556). The microcentrifuge tubes were frozen $\left(-20^{\circ} \mathrm{C}\right)$ and the bottom of the tubes containing the cell pellets were removed with a pair of dog nail clippers. Cell pellets were digested $\left(22^{\circ} \mathrm{C}, 24 \mathrm{~h}, 3 \mathrm{M} \mathrm{HNO}_{3}\right)$ and insoluble cell debris was removed $\left(13000 \mathrm{~g}, 5 \mathrm{~min}, 22^{\circ} \mathrm{C}\right)$. Potassium was determined with a flame photometer (model 2655-00 digital flame analyser; Cole-Parmer Instruments).

Purification of S. bovis HC5 bacteriocin. Stationary-phase $S$. bovis cultures were harvested by centrifugation and the cells were washed in sodium phosphate buffer ( $5 \mathrm{mM}, \mathrm{pH} 6.7)$. The cell pellets were resuspended in acidic sodium chloride $\left(100 \mathrm{mM}, \mathrm{pH} 2 \cdot 0,2 \mathrm{~h}, 4^{\circ} \mathrm{C}\right)$. The cell suspensions were recentrifuged to remove cells and the cell-free supernatant was lyophilized. The lyophilized material was resuspended in sterile water. The bacteriocin extract was then applied to an SP Sepharose column $(1.0 \times 10 \mathrm{~cm}$; Amersham Pharmacia) washed with 3 vols water followed by $0.2 \mathrm{M}$ and $0.4 \mathrm{M} \mathrm{NaCl}$. Multiple $100 \mu \mathrm{l}$ injections of the active fractions were applied to a Discover BIO wide pore C-18 column $[4.6 \times 150 \mathrm{~mm}$, $5 \mu \mathrm{m}$ Supelco, $1 \mathrm{ml} 0 \cdot 1 \%$ trifluoroacetic acid (TFA) in water $\min ^{-1}, 2 \%$ acetonitrile gradient $\min ^{-1}, 22^{\circ} \mathrm{C}$. Antibacterial activity of the eluted fractions was assayed with Bacillus subtilis ATCC 6537, an aerobic bacterium that was also sensitive. The final purification of the active peptide was completed by reinjecting the active fractions onto a Discovery $\mathrm{RP}$ amide C16 column using ethanol as a carrier solvent $(1 \%$ $\min ^{-1}, 4.6 \mathrm{~mm} \times 25 \mathrm{~cm}, 5 \mu \mathrm{m}$ Supelco). The active fractions were then collected and lyophilized.

The purified peptide was separated by Tris/Tricine SDSPAGE (16.5\% acrylamide) (Ausubel et al., 1997). One half of the gel was washed in water $(10 \mathrm{~min})$, and fixed with glutaraldehyde $(5 \%, 1 \mathrm{~h}$; Sigma), prior to staining with Coomassie brilliant blue R-250 (0.025\%, $1 \mathrm{~h}$; Sigma). Gels were destained overnight in acetic acid $(10 \%, \mathrm{v} / \mathrm{v})$. The other half of the gel was fixed $(10 \%$ acetate $/ 20 \% 2$-propanol, v/v, $30 \mathrm{~min})$ and washed with MilliQ- $\mathrm{H}_{2} \mathrm{O}(1 \mathrm{~h})$. The gel was then covered with moist Kimwipes (Kimberly Clark), overlaid with soft agar $(10 \mathrm{ml})$ containing $10^{6}$ cells B. subtilis ATCC 6537 and incubated overnight at $37^{\circ} \mathrm{C}$.

Determination of $\mathrm{N}$-terminal amino acid sequence of bovicin HC5. Purified bacteriocin from $S$. bovis HC5 was subjected to Edman degradation analysis on a PE/ABD Procise $494 \mathrm{cLC}$ Protein Sequencing System (Harvard Microchemistry Facility, Cambridge, MA).

Mass spectrometry of bovicin HC5. The S. bovis HC5 bacteriocin obtained by HPLC purification was added to a matrix-assisted laser desorption ionization time-of-flight (MALDI-TOF) sample plate and the sample was supplemented with $1 \mathrm{ml}$ of an $\alpha$-cyano-4-hydroxy-trans-cinnamic acid solution (10 $\mathrm{mg}$ in $50 \%$ acetonitrile and $0.3 \%$ TFA). The mixture was mixed and allowed to dry at room temperature prior to mass spectrometry. The mass spectrometry data were acquired on a Voyager DE-STR MALDI-TOF MS system (Perspective Biosystems) with delayed extraction in the reflectron mode.

Other analysis. Cell protein was determined by the Lowry method, using serum albumin as a standard. 


\section{RESULTS}

\section{Spectrum of activity}

When S. bovis HC5 was grown anaerobically on basal medium agar plates and overlaid with molten agar containing $S$. bovis JB1 cultures, a distinct zone of clearing was observed (Table 1). S. bovis HC5 also inhibited S. bovis 33317 and 15351, a variety of other Gram-positive bacteria and even Gram-negative Prevotella strains. None of the target bacteria were inhibited when $S$. bovis JB1 (a non-bacteriocin-producing strain) was employed. S. bovis HC5 did not inhibit $S$. bovis 2703, Escherichia coli K-12, Acidaminococcus fermentans ATCC 25085, Selenomonas ruminantium HD4 and D or Megasphaera elsdenii MEAW106. These latter two bacteria are closely related to Gram-positive species, but they have outer membranes (Stackebrandt et al., 1985).

\section{Crude extracts and potassium depletion}

The $S$. bovis HC5 bacteriocin could be precipitated by ammonium sulfate precipitation (40-60\% fraction) and dialysis. The bacteriocin extract retained activity if it was autoclaved $\left(120^{\circ} \mathrm{C}, 20 \mathrm{~min}\right)$ or treated with $12 \mathrm{U}$ proteinase $\mathrm{K} \mathrm{ml}^{-1}$ and $41 \mathrm{U} \alpha$-chymotrypsin $\mathrm{ml}^{-1}$, but it was inactivated by $4 \mathrm{U}$ Pronase $\mathrm{E} \mathrm{ml}^{-1}$ and $11 \cdot 3 \mathrm{U}$

Table 1. Spectrum of activity of partially purified S. bovis HC5 bacteriocin

\begin{tabular}{|lc|}
\hline Bacterial strain & $\begin{array}{c}\text { Zone of } \\
\text { inhibition* }\end{array}$ \\
\hline Streptococcus bovis JB1 & \\
Streptococcus bovis 33317 & ++ \\
Streptococcus bovis 15351 & ++ \\
Streptococcus bovis 2703 & +++ \\
Streptococcus gallolyticus LRC0255 & - \\
Streptococcus equinus 9812 & +++ \\
Ruminococcus albus B199 & ++ \\
Enterococcus faecalis CG110 & +++ \\
Enterococcus faecalis NCK 337 & ++ \\
Clostridium sticklandii SR & ++ \\
Clostridium aminophilum F & ++++ \\
Peptostreptococcus anaerobius C & +++ \\
Butyrivibrio fibrisolvens 49 & ++++ \\
Butyrivibrio fibrisolvens JL5 & +++ \\
Bacillus subtilis ATCC 6537 & +++ \\
Lactobacillus plantarum LII a I & ++++ \\
Lactococcus lactis C2 & +++ \\
Listeria monocytogenes 104035 & ++++ \\
Prevotella bryantii B 4 & +++ \\
Prevotella brevis GA-33 & + \\
Selenomonas ruminantium HD4 & + \\
Selenomonas ruminantium D & - \\
Escherichia coli K-12 & - \\
Acidaminococcus fermentans ATCC 25085 & - \\
Megasphaera elsdenii MEAW106 & + \\
\hline No & + \\
\hline
\end{tabular}

*No inhibition $(-)$ to strong inhibition $(>15 \mathrm{~mm},++++$ ).

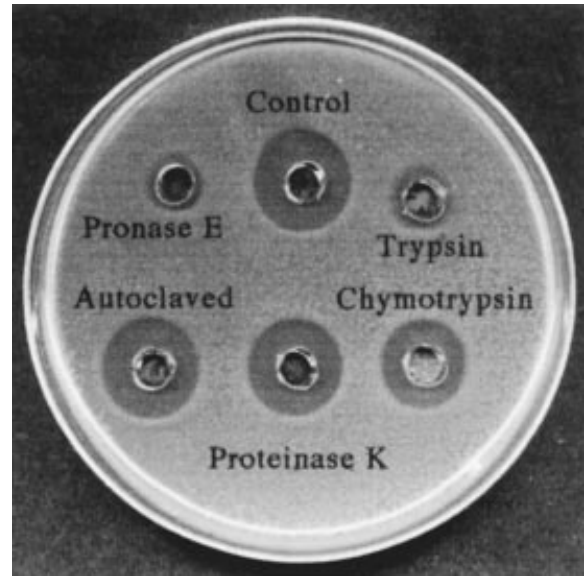

Fig. 1. The effect of proteinases, peptidases and heat $\left(121^{\circ} \mathrm{C}\right.$, $20 \mathrm{~min}$ ) on the activity of partially purified bacteriocin that was added to agar wells. The agar was inoculated with approximately $10^{5} \mathrm{~S}$. bovis JB1 cells and incubated at $39^{\circ} \mathrm{C}$ for $24 \mathrm{~h}$.

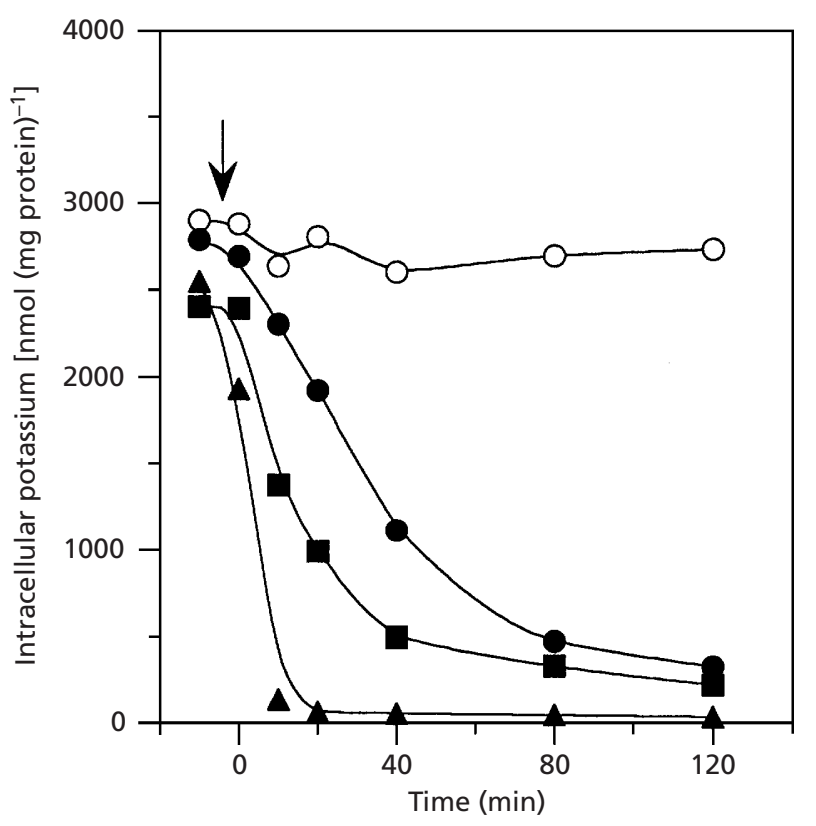

Fig. 2. The effect of $S$. bovis HC5 bacteriocin extracts on the intracellular potassium levels of $S$. bovis JB1 cells that were energized with glucose $(22 \mathrm{mM})$. Cells were treated at time zero (arrow) with extracts that were obtained from culture supernatant ammonium sulfate precipitation (O) or cell pellets that were treated with acidic $\mathrm{NaCl}(\boldsymbol{\square})$. The cells were also treated with $1 \mu \mathrm{M}$ nisin $(\boldsymbol{\Delta})$. Untreated controls $(O)$ are also shown.

trypsin $\mathrm{ml}^{-1}$ (Fig. 1). Bacteriocin extracts that were bubbled with $\mathrm{O}_{2}$ and returned to the anaerobic glove box remained active (data not shown). When the extract was subjected to Tris/Tricine PAGE, a variety of peptides were observed (data not shown).

When stationary-phase $S$. bovis JB1 cells were washed and incubated in a basal medium containing glucose 


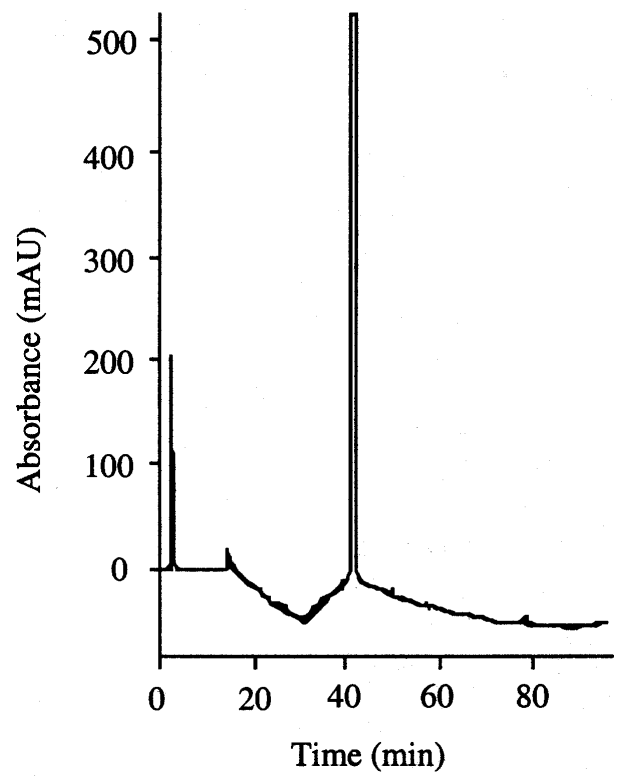

Fig. 3. A high pressure liquid chromatogram of purified bovicin HC5. Extracts obtained from cells by acidic $\mathrm{NaCl}(100 \mathrm{mM}$, $\mathrm{pH} 2.0$ ) and collected from an SP Sepharose column were applied to a C-18 column $(4.6 \times 150 \mathrm{~mm}$, Supelco, $1 \mathrm{ml} 0.1 \%$ TFA in water $\min ^{-1}, 2 \%$ acetonitrile gradient $\min ^{-1}, 22{ }^{\circ} \mathrm{C}$ ).

(22 $\mathrm{mM}$ ) but lacking nitrogen sources, the cells did not grow, but the intracellular potassium was $>2800 \mathrm{nmol}$ $(\mathrm{mg} \text { protein })^{-1}$ (Fig. 2$)$. When $1 \mu \mathrm{M}$ nisin was added, intracellular potassium declined rapidly and virtually no potassium could be detected after $10 \mathrm{~min}$. If bacteriocin extract was added, potassium also declined, but the rate of this decrease was noticeably slower than that observed with nisin. Potassium efflux was not observed if the extract was treated with Pronase E (data not shown).

\section{Purification of the S. bovis HC5 bacteriocin}

The crude bacteriocin extract had contaminating peptides from the basal medium and it appeared that much of the activity was not being recovered. If Tween was deleted from the basal medium, little activity was detected in the culture supernatant. Cells that were harvested by centrifugation and treated with acidic $\mathrm{NaCl}(100 \mathrm{mM}, \mathrm{pH} 2 \cdot 0)$ did not lyse, but they released bacteriocin. The activity (based on the original number of cells) was at least 10 -fold greater than that in ammonium sulfate extracts and the rate of potassium efflux from glycolysing $S$. bovis JB1 cells was faster (Fig. 2).

When the acidic $\mathrm{NaCl}$ extract was applied to an SP Sepharose column, the antibacterial activity could be eluted by $0.4 \mathrm{M} \mathrm{NaCl}$. HPLC (C18 column) indicated that this fraction had a variety of peaks, but only one peak had activity. Rechromatography of the active fraction (RP amide, C16 column) yielded a single purified peptide that had activity (Fig. 3). Tris/Tricine PAGE supported the idea that bacteriocin had indeed

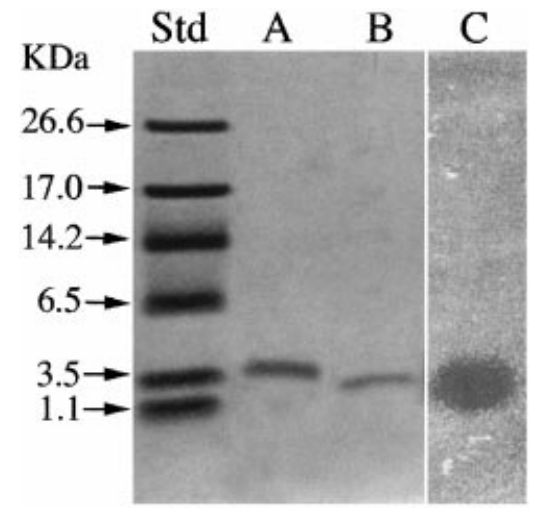

Fig. 4. Tris/Tricine PAGE of nisin (A) and purified bovicin HC5 (B). The gel was fixed with glutaraldehyde and stained with Coomassie brilliant R 250 blue. Molecular mass standards are shown at the left. Lane $C$ shows an unstained PAGE that was overlaid with soft agar containing Bacillus subtilis ATCC 6537.

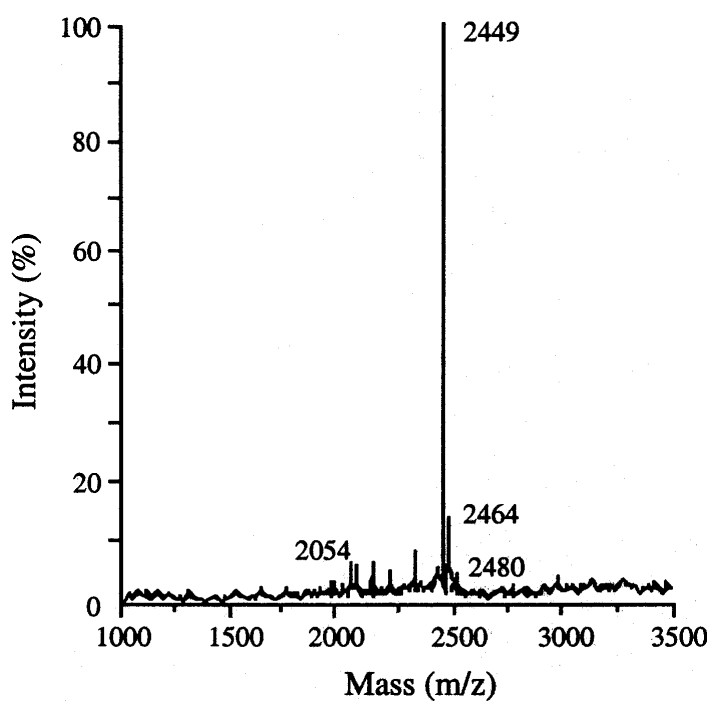

Fig. 5. A MALDI-TOF MS chromatogram of the purified bovicin HC5. Results indicated that the purified bacteriocin had a molecular mass of approximately $2440 \mathrm{Da}$.

been purified (Fig. 4). When the purified bacteriocin was lyophilized and subjected to Edman degradation, the Nterminal amino acid sequence could be determined (VGXRYASXPGXSWKYVXF), but there were four residues (indicated by an $\mathrm{X}$ ) that did not correspond to any of the 20 amino acids commonly found in proteins. Mass spectrometry based on MALDI-TOF indicated that the purified bacteriocin had a molecular mass of approximately $2440 \mathrm{Da}$ (Fig. 5).

\section{DISCUSSION}

Early work (Iverson \& Mills, 1976) indicated that some strains of $S$. bovis produced bacteriocins and Whitford et al. (2001) recently reported that S. gallolyticus 
Bovicin HC5

s. pyogenes lantibiotic
DH
Fig. 6. Alignment of the $\mathrm{N}$-terminal amino acid sequence of bovicin $\mathrm{HC} 5$ and the lantibiotic precursor of S. pyogenes SF370. Identical residues are shown on a black background and conserved substitutions are shown on a grey background.
LRC0255 (a bacterium previously classified as S. bovis) inhibited a variety of streptococci. However, recent work indicated that sterile-filtered S. gallolyticus LRC0255 culture supernatants could not inhibit nisinresistant S. bovis JB1 cultures (Mantovani et al., 2001). Because nisin-resistant cells were bovicin-resistant, and this phenotype develops quickly, it is unlikely that either bovicin 255 or nisin would have a marked impact on $S$. bovis ecology in vivo. However, previous work indicated that $S$. bovis HC5 could inhibit both nisin-sensitive and nisin-resistant $S$. bovis JB1 cultures and a variety of freshly isolated $S$. bovis strains, and adaptation could not be demonstrated (Mantovani et al., 2001). Based on these previous results, it appeared that the $S$. bovis HC5 bacteriocin had potential as an agent to manipulate ruminal ecology and fermentation.

Some bacteriocins are highly specific and can only inhibit closely related strains (Jack et al., 1995), but $S$. bovis HC5 was able to inhibit a variety of Gram-positive ruminal bacteria as well as Gram-positive species from other habitats (Table 1). Sel. ruminantium and M. elsdenii are closely related to Gram-positive bacteria, but these species have outer membranes (Stackebrandt et al., 1985) and were resistant to the antibacterial activity of $S$. bovis HC5. S. bovis HC5 did not inhibit E. coli or A. fermentans, but a small zone of clearing was observed with Prevotella bryantii, a Gramnegative ruminal bacterium that has been used as a model of monensin resistance (Callaway \& Russell, 2000). Based on these results, it appeared that S. bovis HC5 has approximately the same spectrum of activity as monensin, a commonly used antibiotic in cattle rations (Russell \& Strobel, 1989).

The idea that the antibacterial activity of S. bovis HC5 was a bacteriocin was supported by the observation that it could be precipitated by ammonium sulfate and inactivated by Pronase E, a mixture of proteinases and peptidases. The crude extracts were resistant to $\alpha$ chymotrypsin, proteinase $\mathrm{K}$ and heat, and these properties could be advantageous for commercial applications. Many bacteriocins are peptides that insert into cell membranes to form pores, but some bacteriocins are thought to inhibit peptidoglycan synthesis and DNA replication (Jack et al., 1995; Sablon et al., 2000). Because the crude extract catalysed potassium efflux from $S$. bovis JB1, it appeared to contain a pore-forming peptide.

Bacteriocins are frequently cell associated and detergents are often added to the culture media to promote bacteriocin release (Parente \& Ricciardi, 1999; Nel et al., 2001). The bacteriocin activity of S. bovis HC5 cell- free supernatant was greatly enhanced by Tween 80 . Bacteriocin activity could be precipitated from the cellfree supernatant by ammonium sulfate, but it had an abundance of contaminating peptides. Some of these peptides could be removed by dialysis, but even this latter treatment did not remove all of the contamination.

Yang et al. (1992) noted that bacteriocins of some lactic acid bacteria could be dislodged from the cell surface by acidic $\mathrm{NaCl}$, and this treatment liberated S. bovis HC5 bacteriocin without causing detectable cell lysis. Because the cells could be washed prior to the acidic $\mathrm{NaCl}$ treatment, contaminating peptides from the basal medium were largely eliminated. HPLC indicated that the acidic $\mathrm{NaCl}$ extracts had some inactive peptides, but the active peptide could be purified and concentrated by rechromatography. The active peptide could not be silver stained, and other workers have noted a similar phenomenon (Carolissen-Mackay et al., 1997; Pattnaik et al., 2001; Villani et al., 1995). However, it reacted with Coomassie stain after the gel had been fixed with glutaraldehyde (Fig. 4).

Edman degradation analysis indicated that the $\mathrm{N}$ terminal amino acid sequence had 4 amino acid residues that did not correspond to any of the 20 amino acids commonly found in proteins. Lantibiotics have rings that are created from the condensation of cysteine and dehydro-amino acids (e.g. dehydroalanine) (DeVos et al., 1995; Guder et al., 2000). The unnamed amino acids had approximately the same position as the N-terminal dehydroalanines of nisin, subtilin and epidermin, but samples that were reduced and alkylated prior to Edman degradation did not have cysteine residues. Because cysteine residues were not detected under these conditions, it appeared that the unnamed residues were modified or other unusual amino acids.

A BLAST search of GenBank sequences indicated that our $\mathrm{N}$-terminal amino acid sequence was unique. The only other bacteriocin that had significant similarity was the lantibiotic precursor of $S$. pyogenes SF370 (Ferreti et al., 2001), but the identity was only $55 \%$ (Fig. 6). Based on these results, the bacteriocin of S. bovis HC5 appears to be novel and we now designate it as bovicin HC5. Further work will be needed to locate and sequence the bovicin HC5 gene.

\section{ACKNOWLEDGEMENTS}

J.B.R. is a member of the US Dairy Forage Research Center, Madison, WI. H.C.M. was supported by the Conselho Nacional de Desenvolvimento Científico e Tecnológico (CNPq), Brasília, Brazil. The authors thank Jennifer L. Rychlik for technical assistance and valuable discussion. 
Proprietary or brand names are necessary to report factually on available data; however, the USDA neither guarantees nor warrants the standard of the product, and the use of the name by the USDA implies no approval of the product, and exclusion of others that may be suitable.

\section{REFERENCES}

Ausubel, F., Brent, R., Kingston, R. E., Moore, D. D., Seidman, J. G., Smith, J. A. \& Struhl, K. (1997). Short Protocols in Molecular Biology, 3rd edn. New York: Wiley.

Callaway, T. R. \& Russell, J. B. (2000). Variations in the ability of ruminal gram-negative Prevotella species to resist monensin. Curr Microbiol 40, 185-190.

Callaway, T. R., Carneiro De Melo, A. M. S. \& Russell, J. B. (1997). The effect of nisin and monensin on ruminal fermentations in vitro. Curr Microbiol 35, 90-96.

Carolissen-Mackay, V., Arendse, G. \& Hastings, J. W. (1997). Purification of bacteriocins of lactic acid bacteria: problems and pointers. Int J Food Microbiol 34, 1-16.

Cotta, M. A. \& Russell, J. B. (1982). Effect of peptides and amino acids on efficiency of rumen bacterial protein synthesis in continuous culture. J Dairy Sci 65, 226-234.

De Vos, W. M., Kuipers, O. P., van der Meer, J. R. \& Siezen, R. J. (1995). Maturation pathway of nisin and other lantibiotics: posttranslationally modified antimicrobial peptides exported by Gram-positive bacteria. Mol Microbiol 17, 427-437.

Ferretti, J. J., McShan, W. M., Ajdic, D. \& 20 other authors (2001). Complete genome sequence of an M1 strain of Streptococcus pyogenes. Proc Natl Acad Sci US A 98, 4658-4663.

Guder, A., Wiedemann, I. \& Sahl, H.-G. (2000). Post-translationally modified bacteriocins - the lantibiotics. Biopolymers 55, 62-73.

Iverson, W. G. \& Millis, N. F. (1976). Bacteriocins of Streptococcus bovis. Can J Microbiol 22, 1040-1047.

Jack, R. W., Tagg, J. R. \& Ray, B. (1995). Bacteriocins of Grampositive bacteria. Microbiol Rev 59, 171-200.

Kalmokoff, M. L., Bartlett, F. \& Teather, R. M. (1996). Are ruminal bacteria armed with bacteriocins? J Dairy Sci 79, 2297-2306.

Mantovani, H. C. \& Russell, J. B. (2001). Nisin resistance of Streptococcus bovis. Appl Environ Microbiol 67, 808-813.
Mantovani, H. C., Kam, D. K., Ha, J. K. \& Russell, J. B. (2001). The antibacterial activity and sensitivity of Streptococcus bovis strains isolated from the rumen of cattle. FEMS Microbial Ecol 37, 223-229.

Nel, H. A., Bauer, R., Vandamme, E. J. \& Dicks, L. M. T. (2001). Growth optimization of Pediococcus damnosus NCFB 1832 and the influence of $\mathrm{pH}$ and nutrients on the production of pediocin PD-1. J Appl Microbiol 91, 1131-1138.

Parente, E. \& Ricciardi, A. (1999). Production, recovery and purification of bacteriocins from lactic acid bacteria. Appl Microbiol Biotechnol 52, 628-638.

Pattnaik, P., Kaushik, J. K., Grover, S. \& Batish, V. K. (2001). Purification and characterization of a bacteriocin-like compound (lichenin) produced anaerobically by Bacillus licheniformis isolated from water buffalo. J Appl Microbiol 91, 636-645.

Russell, J. B. \& Rychlik, J. L. (2001). Factors that alter rumen microbial ecology. Science 292, 1119-1122.

Russell, J. B. \& Strobel, H. J. (1989). Mini-Review: the effect of ionophores on ruminal fermentation. Appl Environ Microbiol 55, 1-6.

Sablon, E., Contreras, B. \& Vandamme, E. (2000). Antimicrobial peptides of lactic acid bacteria: mode of action, genetics and biosynthesis. Adv Biochem Eng 68, 21-60.

Stackebrandt, E., Pohla, H., Kroppenstedt, R., Hippe, H. \& Woese, C. R. (1985). $16 \mathrm{~S}$ rRNA analysis of Sporomusa, Selenomonas, and Megasphaera: on the phylogenetic origin of Gram-positive eubacteria. Arch Microbiol 143, 270-276.

Villani, F., Pepe, O., Mauriello, G., Salzano, G., Moschetti, G. \& Coppola, S. (1995). Antilisterial activity of thermophilin 347, a bacteriocin produced by Streptococcus thermophilus. Int J Food Microbiol 25, 179-190.

Whitford, M. F., McPherson, M. A., Forster, R. J. \& Teather, R. M. (2001). Identification of bacteriocin-like inhibitors from rumen Streptococcus spp. and isolation and characterization of bovicin 255. Appl Environ Microbiol 67, 569-574.

Yang, R., Johnson, M. \& Ray, B. (1992). Novel method to extract large amounts of bacteriocins from lactic acid bacteria. Appl Environ Microbiol 58, 3355-3359.

Received 2 April 2002; revised 25 June 2002; accepted 15 July 2002. 